\title{
PROSTATE DISEASES IN THE DOG
}

\section{J. RINCK ${ }^{1}$, R. RINCK ${ }^{2}$, M. RINCK ${ }^{3}$, R. SABOCANEC ${ }^{4}$, K. ČULJAK ${ }^{4}$, B. NJARI ${ }^{5}$,} A. HADIOSMANOVIC ${ }^{6}$, M. VUCEMILO ${ }^{6}$

${ }^{1} \mathrm{~J}$. W. Goethe Universitätklinik, Frankfurt/Main, ${ }^{2}$ Kleintierpraxis Karben, Germany, ${ }^{3}$ Veterinary Faculty, University of Zagreb, ${ }^{4}$ Department of Pathology, ${ }^{5}$ Department of Food Hygiene, ${ }^{6}$ Department of Zoohygiene, Veterinary Faculty, University of Zagreb, Croatia

Received March 20, 1997

Accepted March 3, 1998

\begin{abstract}
Rinck J., R. Rinck, M. Rinck, R. Sabočanec, K. Culjak, B. Njari, A. Hadiosmanovič, M. Vučemilo: Prostate Diseases in the Dog. Acta vet. Brno 1998, 67: 59-64.

A retrospective study is presented of prostatic diseases diagnosed in 32 dogs over a period of 26 years in a private veterinary practice. Of the 32 diseased dogs, 19 patients were aged 6-10 years, 11 dogs were 11-15 years of age, and 2 animals were younger than 5 years. An unusual case of prostate carcinoma in a 2-year-old Dobermann is documented.

Based on clinical, radiographic and ultrasonographic examination completed by bacteriological and laboratory tests, prostatitis was diagnosed in 6 animals. In 26 dogs prostatic hyperplasia was found by rectal examination, and elevated serum acid phosphatase concentration indicated neoplasms. Hormone therapy (Cyproteronacetate, Diethylstilbestrol) was used in 21 dogs with hyperplastic prostate for 4 weeks. However, four months later all dogs were castrated as hyperplasia reoccurred. Castration resulted in a permanent improvement in ca $40 \%$ of patients. Hyperplasia tended to diminish after castration, and in material collected 6 months later by fineneedle transurethral biopsy, carcinoma was still diagnosed in 3 dogs.

Our findings confirm more frequent prostastic diseased in aged dogs. Occurrence and frequency of prostatic tumours in dogs can be ascribed to hormonal dysbalance. Hormone therapy cannot cure the malignancies but may bring relief. Castration is the method of choice.
\end{abstract}

Prostatic hyperplasia, prostatitis, castration, hormone therapy

Prostatic disease may become a problem in older non-castrated dogs. Cystic or adenomatous hyperplasia are a common disease in this age group (Vladar 1994; Corazza et al. 1994; Nickel and Teske 1992; Gilson et al. 1992; Chang et al. 1996; Maulton 1990; Krawiec and Heflin 1992). Another cause of hyperplasia may be bacterial prostatitis (Nickel and Teske 1992; Krawiec and Heflin 1992; Bell et al. 1995). Among tumours of the canine prostate gland the most frequently described is adenocarcinoma(Vladar 1994; Corazza et al. 1994; Nickel and Teske 1992; Gilson et al. 1992; Chang et al. 1996; Maulton 1990; Krawiec and Heflin 1992). Sarcoma and epithelial carcinoma are occasionally diagnosed, too.

Valuable diagnostic tools are fine-needle biopsy (Nickel and Teske 1992) and laboratory tests, especially acid phosphatase and its prostatic isoenzyme (Bell et al. 1995).

Malignancies are characterized by slow growth. Therefore in many cases they are asymptomatic until a well developed stage when they may form an extremely hard induration or a knot-like structure before they are diagnosed. The most frequent diagnosis of hard and irregular hyperplasias is carcinoma. During further growth, the induration may 
become fixed to the rectum and lateral wall of the pelvis. Such prostatic enlargements can be easily palpated and differentiated from granulomatous prostatitis.

Hormonal therapy of prostatic diseases has been reported (Vladar 1994; Furr 1996), and a dependence of the growth of tumours on the hormonal concentrations was established. Another therapeutic approach is castration that usually results in a slow-down in growth of the tumours (Vladar 1994; Metzger et al. 1993; Krawiec and Heflin 1992; Maulton 1990).

\section{Materials and Methods}

In a veterinary practice, 32 male dogs with prostatic diseases were diagnosed since 1972 . Ages and breeds are presented in Table 1.

The overall health status was poor in some animals, and their clinical symptoms included apathy, dull hair coat, painful movement, tenesmus.

Clinical examination including rectal digital palpation was carried out in all patients, along with lateral and/or ventral abdominal radiography, and ultrasonography. In 25 dogs fine-needle biopsy of the gland was done. Bacteriological examination and serum prostatic acid phosphatase (Test - Combination Saure Phosphatase, Boehringer, Mannheim, Germany) was determined spectrophotometrically in all patients. In 11 patients also a finecatheter biopsy was carried out. Moreover, in 4 animals pathohistological examination was done.

Table 1

\begin{tabular}{|c|c|c|c|c|}
\hline No. & Breed Age & $\begin{array}{l}\text { Ultrasonographic } \\
\text { examination }\end{array}$ & Bacteriology & $\begin{array}{l}\text { Castra- } \\
\text { tion }\end{array}$ \\
\hline 1 & German shepherd & normal size gland & hemolytic E. coli & - \\
\hline 2 & German shepherd & cystic enlarg. of prostate \& bladder & negative & + \\
\hline 3 & Dobermann & cystic enlarg. of prostate $\&$ bladder & negative & + \\
\hline 4 & Poodle & prostatic hyperplasia & hemolytic E. coli & + \\
\hline 5 & Poodle & normal size prostate & hemolytic E. coli & - \\
\hline 6 & Dobermann & cystic enlarg. of prostate $\&$ bladder & negative & + \\
\hline 7 & Great Dane & cystic enlarg. of prostate $\&$ bladder & hemolytic E. coli & + \\
\hline 8 & Cocker spaniel & prostatic hyperplasia & hemolytic E. coli & + \\
\hline 9 & Rottweiler & cystic enlarg. of prostate $\&$ bladder & negative & + \\
\hline 10 & Terrier & prostatic hyperplasia & hemolytic E. coli & + \\
\hline 11 & New Foundland & cystic enlarg. of prostate \& bladder & Staphylococcus sp. & + \\
\hline 12 & St. Bernard & normal size prostate & hemolytic E. coli & - \\
\hline 13 & Dachshund & prostatic hyperplasia & negative & + \\
\hline 14 & German shepherd & prostatic hyperplasia & hemolytic E. coli & - \\
\hline 15 & German shepherd & cystic enlarg. of prostate $\&$ bladder & Cryptococcus pyocyaneus & + \\
\hline 16 & German shepherd & prostatic hyperplasia & hemolytic E. coli & + \\
\hline 17 & Great Dane & normal size prostate & Staphylococcus aureus & + \\
\hline 18 & Afghane & normal size prostate & hemolytic E. coli & - \\
\hline 19 & Great Dane & prostatic hyperplasia & hemolytic E. coli & + \\
\hline 20 & Great Dane & cystic enlarg. of prostate $\&$ bladder & negative & + \\
\hline 21 & Dobermann & cystic enlarg. of prostate \& bladder & negative & + \\
\hline 22 & Dobermann & prostatic hyperplasia & negative & + \\
\hline 23 & Poodle & prostatic hyperplasia & negative & + \\
\hline 24 & Foxterrier & normal size prostate & hemolytic E. coli & + \\
\hline 25 & Poodle & cystic enlarg. of prostate \& bladder & hemolytic E. coli & + \\
\hline 26 & German shepherd & cystic enlarg. of prostate \& bladder & negative & - \\
\hline 27 & Cocker spaniel & prostatic hyperplasia & hemolytic E. coli & - \\
\hline 28 & Afghane & normal size prostate & hemolytic E. coli & - \\
\hline 29 & Rottweiler & cystic enlarg. of prostate \& bladder & negative & - \\
\hline 30 & Poodle & prostatic hyperplasia & negative & + \\
\hline 31 & Golden retriever & cystic enlarg. of prostate $\&$ bladder & hemolytic E. coli & + \\
\hline 32 & Poodle & prostatic hyperplasia & negative & - \\
\hline
\end{tabular}

Laboratory examination for acid phosphatase revealed normal concentrations in dogs No. 1, 5, 12, 18, 24, and 28 


\section{Results}

The results of selected examinations are summarized in Table 1 . The overall health state was good in 8 dogs, and poor in 24 animals.

In 4 animals, prostatic malignancies expanded in metastases to pelvic bones, iliac lymph nodes and lumbal vertebral column.

Serum acid phosphatase concentration, indicative of neoplasm, was elevated in $26 \mathrm{dogs}$; it was also elevated in animals with diagnosed hyperplasia or cystic or other benign hyperplasia. Repeatedly elevated concentration of this enzyme indicated local or metastatic growth of malignancies. After treatment with anti-androgens, however, the enzyme concentration tended to diminish, and increase when the process recurred (one case of a 2-year-old Dobermann). On the other hand, in 6 animals diagnosed with prostatitis no prostate hyperplasia neither acid phosphatase was elevated. The bacteriological culture of prostatic exprimate yielded positive results in most cases. The most common findings were hemolytic $E$. coli.

Prostatitis was found in 6 dogs. It was always an acute infection accompanied by high fever, tenesmus, perineal and lumbal pain, and impaired miction. The prostate was not enlarged or only slightly but was very painful on digital palpation. The prostatic exprimate culture showed in two cases Staphylococcus spp., in one dog Cryptococcus pyocyaneus, and in the majority of positive findings hemolytic E. coli was isolated. Acute cystitis was present in most dogs with acute prostatitis, and the same microorganisms were found in their urine.

In 26 animals rectal digital palpation resulted in suspect prostatic disease. Therefore ultrasonographic examination and biopsy followed. Twelve of these dogs also had a cystic hyperplasia. Plate XXI, Fig. 1 shows results of an ultrasonographic examination, and Fig. 2. radiographic examination in a 2-year-old Dobermann with unusually advanced cystic hyperplasia, enlarged bladder and a full rectum. Defecation and micturition were impaired in this animal. After castration, in 4 months the prostate size was diminished (Plate XXII., Fig. 3).

\section{Therapy}

The treatment of prostatitis was based on bacteriological examination, completed by resistance test, and the suitable antibiotics (Penicillin, $20000 \mathrm{i} . \mathrm{u}^{\mathrm{kg}} \mathrm{kg}^{-1}$ ) were administered. Analgetics (Novalgin, Boehringer, Germany, $1 \mathrm{mg}$ per $10 \mathrm{~kg}$ body mass) were given as well. Prostatic neoplasms were first treated hormonally with the aim to reduce the androgenic stimulation of the tumour. This therapy was found appropriate in $21 \mathrm{dogs}$, and the treatment with antiandrogenic (cyproteronacetate, $0.4 \mathrm{~g}$ orally) or estrogenic effect (diethylstilbestrol, $0.5 \mathrm{~g}$ orally) was given daily for 4 weeks. In these patients, a temporary pain relief occurred, and an improvement of overall condition. However, no permanent improvement was achieved, and 4 months later, all dogs were castrated because of advanced stage of the disease. In four dogs, castration resulted in healing of the process, in another two animals, prostatectomy was done. Four dogs were euthanatized on request of their owners because of metastases in the pelvis, pelvic lymph nodes and spine.

Advanced processes that regressed after castration were checked 6 month after operation using transurethral fine-needle biopsy. In three animals prostatic carcinoma was present. This was also the case in a 2-year-old Dobermann in which prostatic carcinoma advanced to metastates in pelvis, urinary bladder and urethra so that the animal was euthanatized. Therefore pathomorphological and pathohistological examination was done and documented (see Plate XXII., Fig. 4, Plate XXIII., Fig. 5, 6 and Plate XXIV., Fig. 7). 
Pathomorphological findings

A rather unusual case of prostatic carcinoma in a 2-year-old Dobermann is documented in more detail as fallows:

The prostate was of hazelnut size $1.5-2 \mathrm{~cm}$ in diameter, of a hard consistency and was firmly attached to the underlying issue. On cross-section, a disseminated, coarse and coherent structure, prominent over the cut surface, was found. In this animal, metastases in ureters were also diagnosed (see Plate XXII., Fig. 4, and Plate XIII., Fig. 5).

Pathohistogical findings in prostatic carcinoma is presented (see Plate XXIV., Fig. 7a, b, $c, d$ ). The prostatic stroma was thick and contained fibrotic tissue and smooth muscle fibers. In the stroma, enlarged blood vessels and single mononuclear proliferations in the form of small and medium granular islets were found. The epithelial cells were of different shapes and sizes, and granular structure. Numerous acini were small and showed a cystic enlargements. Single acini with irregular appearance were present. In various places of acini disseminated mononuclear cells of different sizes were found.

These findings were indicative of primary prostatic carcinoma with characteristic sings of cirrhotic changes.

\section{Discussion}

Our findings give further support to numerous literature data in that prostatic diseases become more frequent with advancing age of male dogs. In our group of 32 patients, only 2 animals were younger than 7 years. Similar to descriptions of Nickel and Teske (1992) and Chang et al. (1996), we assume that the high incidence of prostatic tumours in aged dogs is due to their impaired hormone balance.

Our results of urethra examinations have shown that at the beginning of the disease multiple fibroadenomatous nodules originating in the paraurethral region can be found. These structures are mostly malignant at later examinations. Similar findings were reported by Gilson et al. (1992).

Bacterial prostatitis was diagnosed in 5 of 6 examined dogs. These animals were constantly kept outdoors. As the disease incidence is higher in cold periods of the year, possible effects of low ambient temperature on the origin of the disease should be considered. Since in our group of patients there were only six animals suffering from prostatitis, we cannot confirm the opinion of Krawiec and Heflin (1992) about this disease being common in dogs. In all six patients with prostatitis, bacterial agents were isolated, namely hemolytic E. coli, Staphylococcus spp. and Cryptococcus pyocyaneus.

Among our patients, a relatively high incidence of prostatic problems was diagnosed in German shepherd ( 7 out of 32) dogs. This does not suggest a higher incidence in this breed but rather reflects its the regional frequency. Another interesting fact is the a small Dobermann population in the same geographical area counting one animal per ca 200 German shepherds. However, in our group of patients Dobermann had a rather high incidence of the disease, almost as high as German shepherd. This finding should make us think whether this breed is not more predisposed to prostatic disease than other breeds. More frequent incidence of prostatic diseases in Dobermann is also mentioned by $\mathrm{Krawiec}$ and Heflin (1992). Findings in our 2-year-old patient that does not fit into the usual age group of prostatic disease in dogs support this idea.

Cystic prostatic hyperplasia at an incipient stage shows no clinical symptomatology and is benign. However, most patients are presented after the hyperplastic gland has grown substantially and exerts such pressure on the bladder or rectum that the dog has serious 
problems with elimination. At this stage of the disease there may be no other solution than euthanasia. We had four such patients in the group. Non-malignant prostatic hyperplasia was hormonally treated with good results in 13 patients.

In malignant prostatic carcinoma found in our cases, the tumour growth resisted, as in cases described by other authors, hormone therapy, castration or prostatectomy.

Metastates occur in pelvic bones, iliac lymph nodes, ureters and bladder (Vlad ar 1994). However, carcinoma may also be diagnosed with no hyperplastic changes of the gland as shown in Fig. 6 and 7. In this case, prostate of normal size revealed malignancy with metastases in adjacent organs (see Fig. 4).

Prostatic carcinoma may also be accompanied by cystic hyperplasia. In one of our patients, instituted hormone therapy followed by castration resulted in dimished size of the gland. However, malignancy remained and later on metastases were found in adjacent regions (see Fig. 4).

Our group of 32 patients is relatively small to allow for significant statements. The most important outcome is that in more than $90 \%$ of cases, rectal palpation revealed the problem, similar to conclusions of Maulton (1990) and Krawiec and Heflin (1992). Therefore, along with laboratory tests, preventive rectal palpation should become a routine part of examination in older patients even if there are no signs of tenesmus or other changes of eliminatory behaviour.

\section{Nemoci prostaty u psů}

Retrospektivní studie analyzuje nemoci prostaty u 32 psů za údobí 26 let v privátní veterinární praxi. Mezi těmito pacienty bylo 19 ve věku 6-10 let, 11 ve věku 11-17 let, a pouze 2 psi byli mladší pěti let.

Na základě klinického, rtg. a ultrasonografického vyšetření, doplněného o bakteriologické a laboratorní vyšetření, jsme diagnostikovali prostatitis u šesti pacientů. U 26 psů byla rektálním vyšetřením zjištěna hyperplazie prostaty, a zvýšená koncentrace kyselé fosfatázy v krevním séru potvrdila neoplastické bujení.

Hormonální terapie aplikovaná po dobu 4 týdnů (Cyproteronacetate, Diethylstilbestrol) byla použita u 21 psů s hyperplazií prostaty. Avšak po uplynutí 5 měsícủ byli všichni psi kastrováni pro recidivující hyperplazii prostaty. Kastrace zlepšila zdravotní stav u $40 \%$ pacientů.

Hyperplazie měla tendenci se po kastraci zmenšovat, ale ve vzorcích transuretrálních bioptátů, odebraných po 6 měsících byl karcinom prostaty opět diagnostikován.

Naše nálezy potvrzují častější výskyt onemocnění prostaty u staršich psủ. Jejich výskyt a frekvenci lze přičítat hormonální dysbalanci. Hormonální terapie sice neoplastické onemocnění nevyléčí, ale může pacientům ulevit. Metodou volby je kastrace.

\section{References}

BELL, F.W., KLAUSNER, J. S., HAYDEN, D. W., LUND, E. M., LIEBENSTEIN, B. B., FEENEY, D. A., JOHNSTON, S.D., SHIVERS, J.L., EWING, C.M., ISAACS, W. B. 1995: Evaluation of serum and seminal plasma markers in the diagnosis of canine prostatic disorders. J. Vet. Intern. Med. 9: 149-153

CHANG, S. E. BUONACCORSI, G., MACROBERT, A., BROWN, S. G. 1996: Interstitial and transurethral photodynamic therapy of the canine prostate using meso-tetra(m-hydroxyphenyl)chlorin. Int. J. Cancer 67: 555562

CORAZZA, M., GUIDI, G., ROMAGNOLI, S., TOGNETTI, R., BUONACCORSI, A. 1994: Serum total prostatic and non-prostatic acid phosphatase in healthy dogs and in dogs with prostatic diseases. J. Small Anim. Pract. 35: 307-310

FURR, B. J. 1996: The development of Casodex (bicalutamide): preclinical studies. Eur. Urol., Suppl. 2: 83-95 
GILSON, S. D., MILLER, R. T., HARDIE, E. M., SPAULDING, K. A. 1992: Unusual prostatic mass in a dog. JAVMA 200: 702-704

KRAWIEC, D. R., HEFLIN, D. 1992: Study of prostatic disease in dogs: 177 cases (1981-1986). JAVMA 200: 1119-1122

MAULTON, J. E. 1990: Tumor in domestic animals B: Edition Genital System, pp. 487-517

METZGER, F. L., HATTEL, A.L., WHITE, D. G. 1993: Hematuria, hyperestrogenemia, and hyperprogesteronemia due to a Sertoli-cell tumor in a bilaterally cryptorchid dog. Canine practice 18: 32-35

NICKEL, R. F., TESKE, E. 1992: Diagnosis of canine prostatic carcinoma. Tijdsch.voor Diergeneeskunde 117: Suppl. 1, 32 p.

VLADAR, S. 1994: Prostatic diseases in the dog. Kisálatorvos 1: 16-19 
Plate XXI.

Rinck J. et al.: Prostate Diseases... pp. 57-62
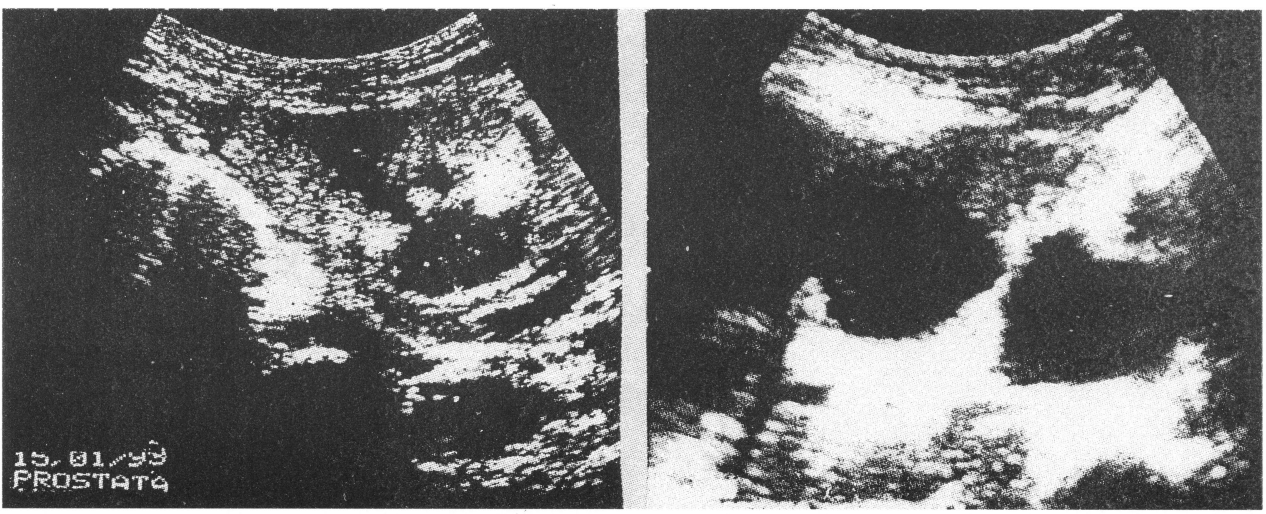

Fig. 1. Ultrasonographic presentation of cystical changes of prostate (1-cysts) in a patient with full bladder. Sektorscanner at $6 \mathrm{MHz}$.

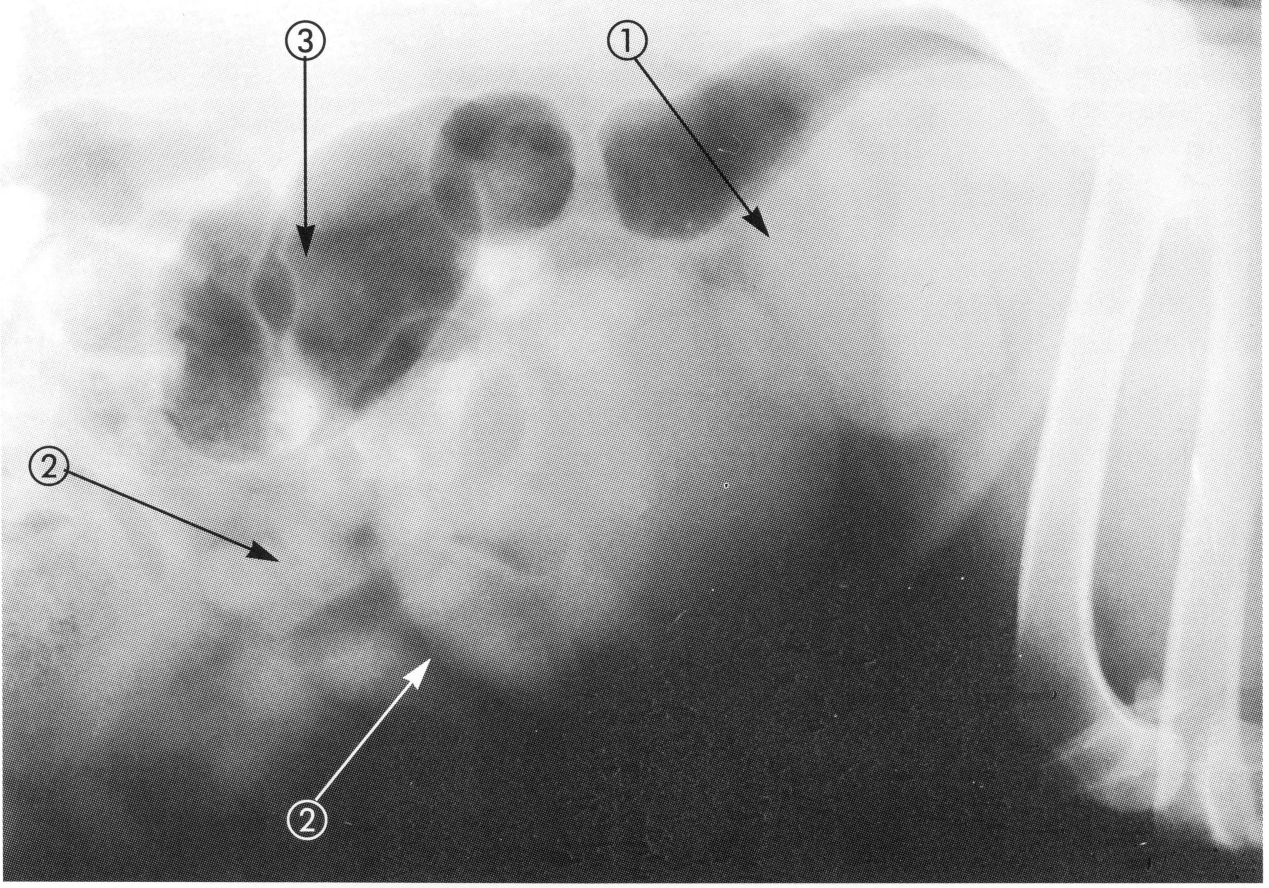

Fig. 2. Radiographic presentation of prostatic hyperplasia (arrow 1), filled bladder (arrow 2), and a filled rectum (arrow 3 ). 


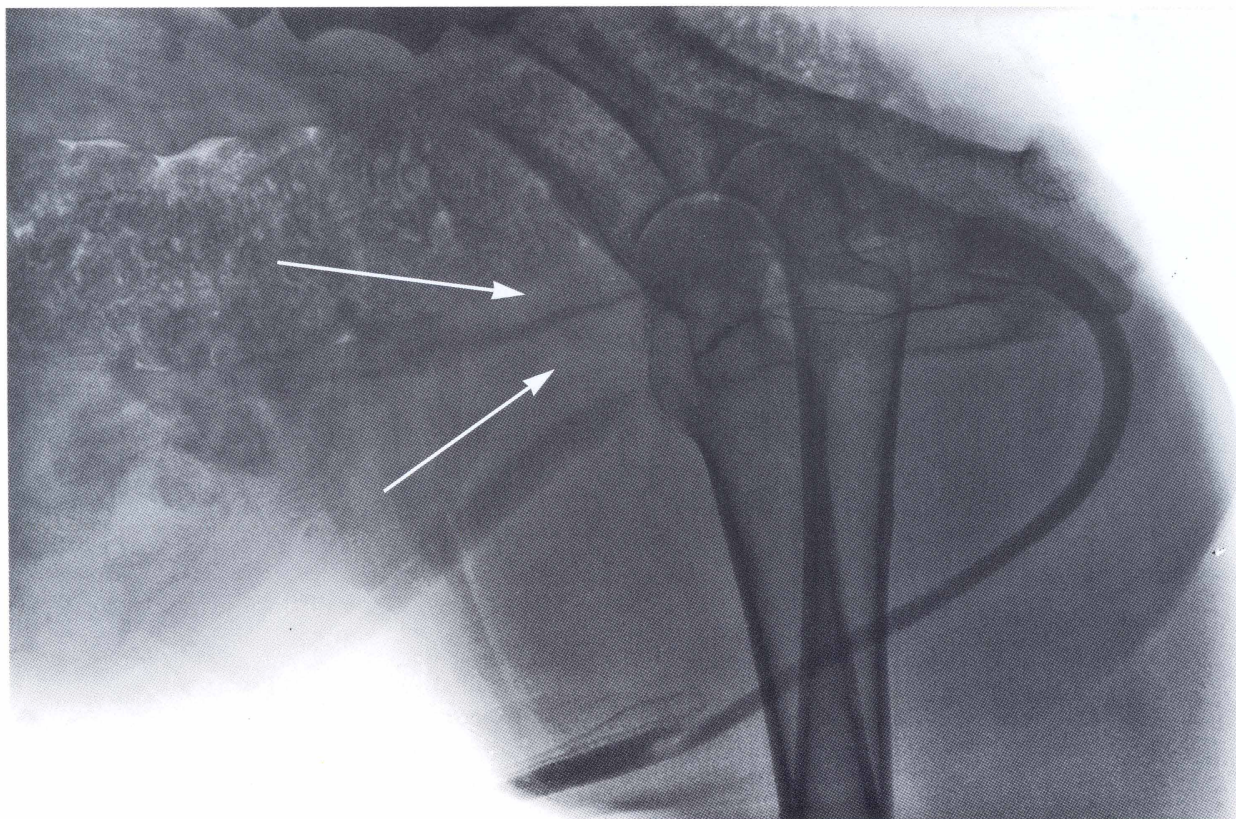

Fig. 3. Radiographic presentation of diminished prostate 4 months after castration.

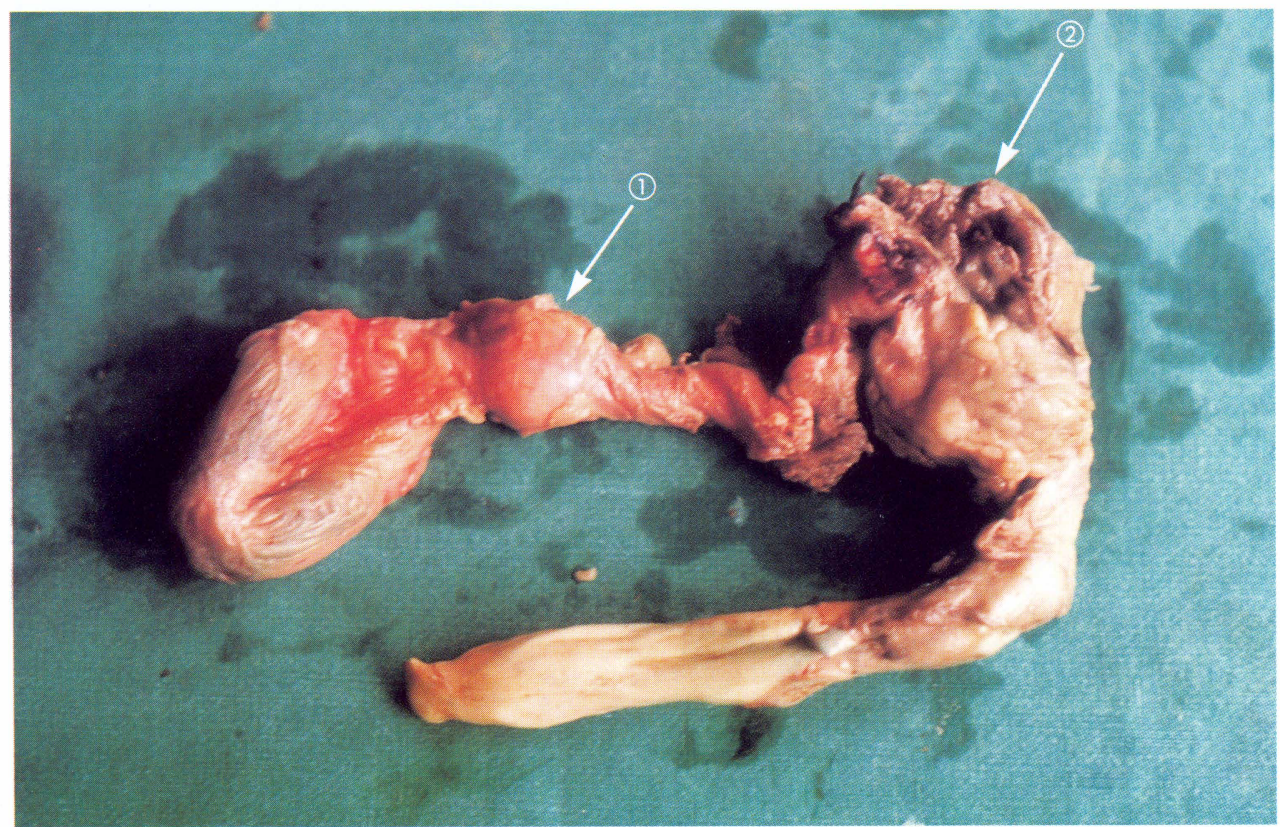

Fig. 4. Cirrhotic carcinomatous prostate (arrow 1) with metastases in ureter (arrow 2). 


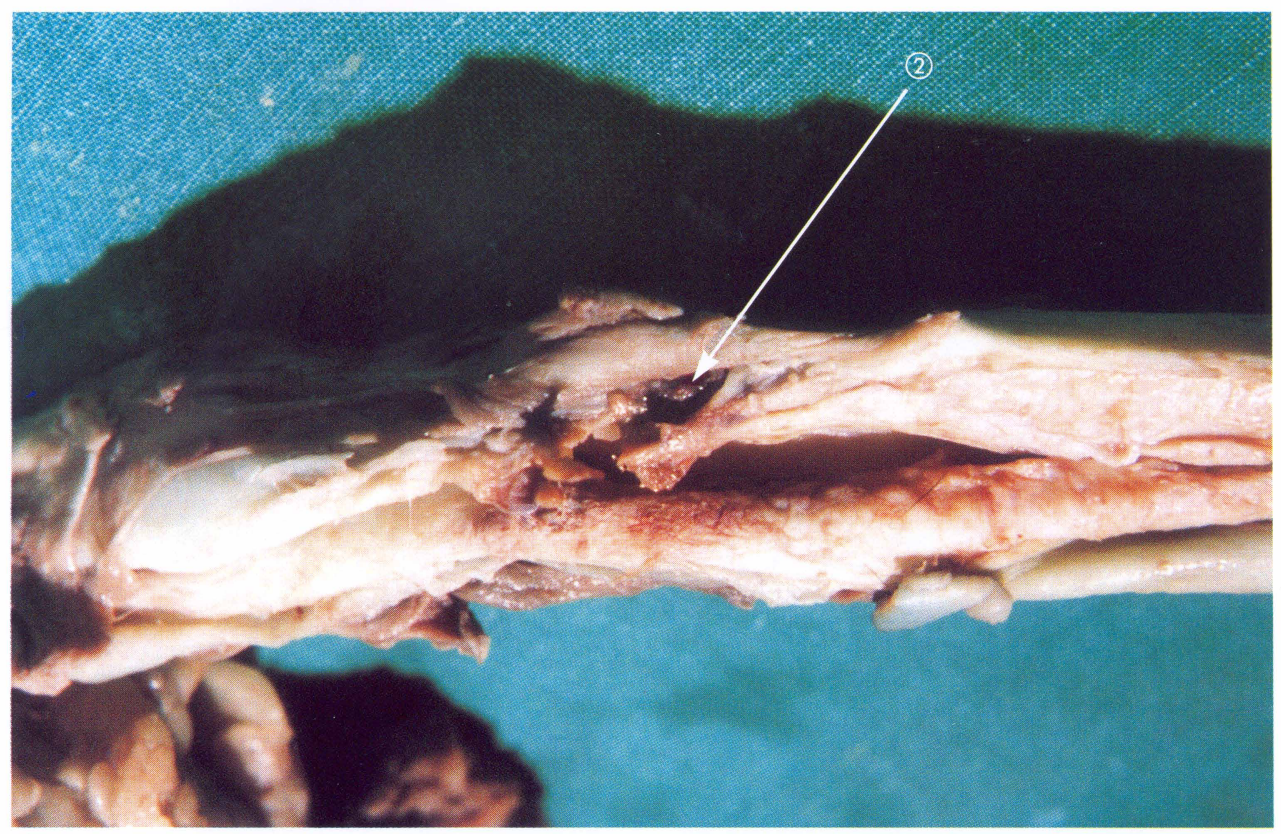

Fig. 5. Metastases in ureter (arrow 2).

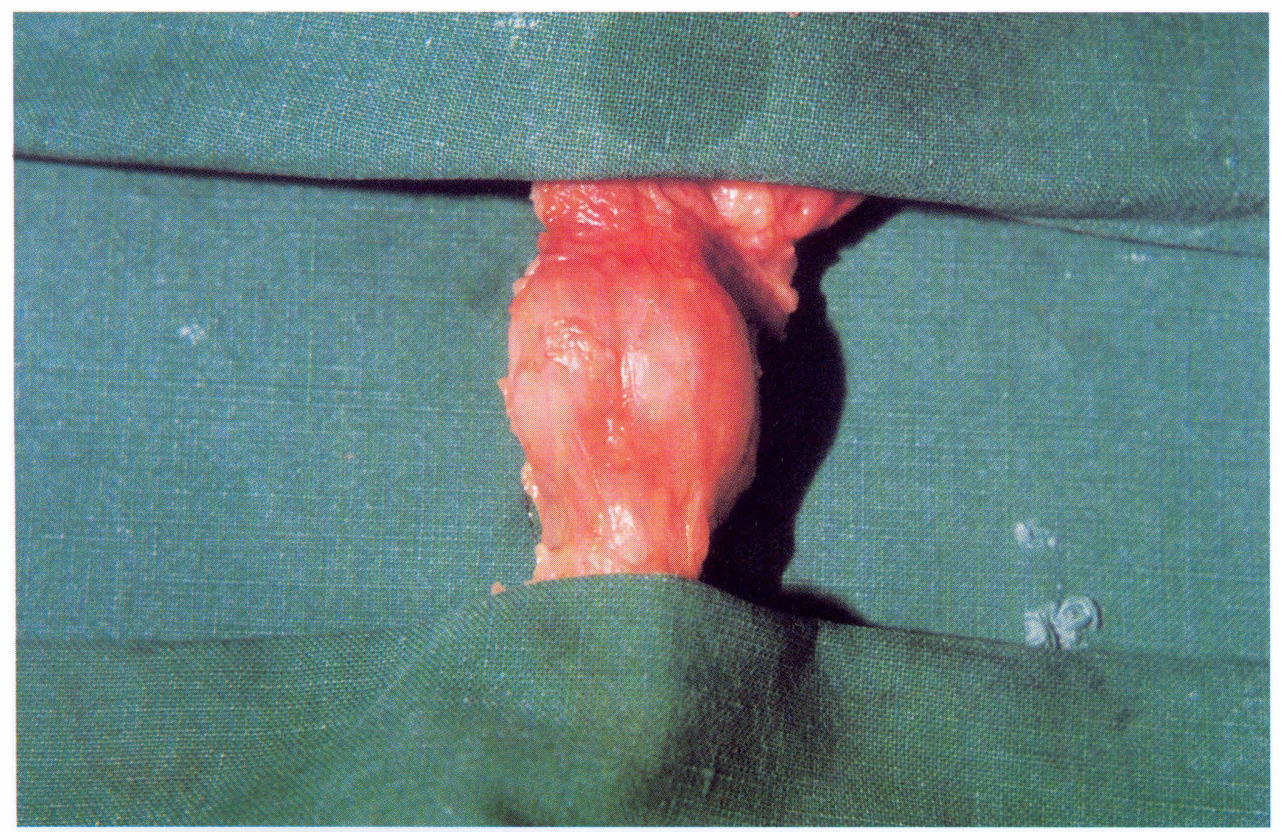

Fig. 6. Prostate size diminished after hormone therapy (when compared with Fig. 1). 
Plate XXIV.

A

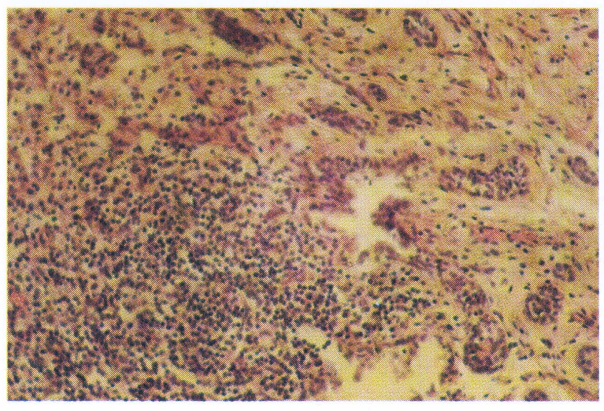

C

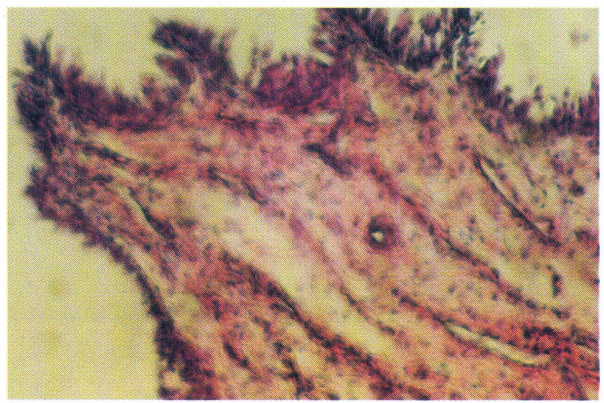

B

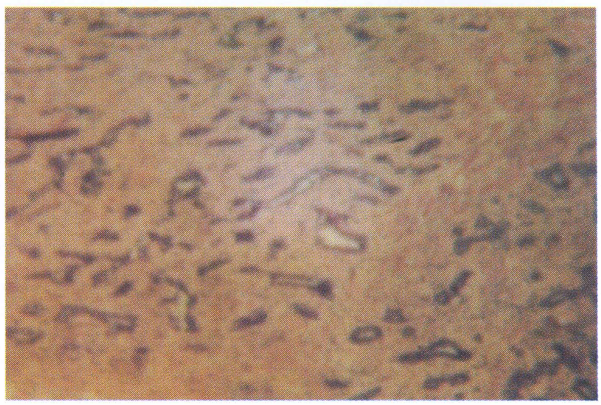

D

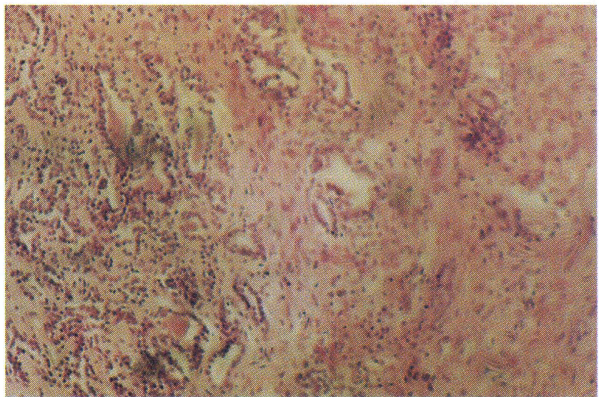

Fig. 7. Carcinomatous prostate. A: follicular-mononuclear proliferation of the gland, B: diminished sizes of acini, C: finger-like carcinomatous proliferation of prostate in its caudal portion, D: adenocarcinoma of prostate. 